\title{
A MODEL STUDY OF BLOOD FLOW IN BRANCHING VESSELS
}

St. Petersburg State University, 7-9, Universitetskaya nab.,

St. Petersburg, 199034, Russian Federation

The purpose of research was to develop a mathematical model for pulsating blood flow in large blood vessels with complex spatial geometry including branching. A part of the aorta with its branches was chosen as an example. The blood vessels were considered as non-deformable curved cylinders. The blood was considered as incompressible non-Newtonian liquid with the power kind of relationship between the stress and shift velocity. The pulse flow pattern was created presetting the pulsating parabolic velocity profile as the boundary condition at the input cross-section. The calculations were performed with use of the computation system ABAQUS. As result the distributions of stress and velocity at the each time moment were obtained. In doing so the generations of the vortexes and reverse flows were revealed. Refs 9. Figs 10.

Keywords: mathematical modelling, blood flow, branching vessels, distributions of stress and velocity.

\section{В. П. Трегубов, Д. Х. Мухтарова}

\section{МОДЕЛЬНОЕ ИЗУЧЕНИЕ ТЕЧЕНИЯ КРОВИ В ВЕТВЯЩИХСЯ СОСУДАХ}

Санкт-Петербургский государственный университет, Российская Федерация, 199034, Санкт-Петербург, Университетская наб., 7-9

\begin{abstract}
Целью проведенного исследования было создание математической модели пульсирующего течения крови по крупным кровеносным сосудам сложной пространственной геометрии, включая их ветвления. В качестве примера для моделирования был выбран участок аорты, включающий восходящий отдел, дугу аорты с ее ответвлениями и верхнюю часть нисходящего отдела. Поскольку деформации этой части аорты малы, при построении механической модели ее стенки считались абсолютно твердыми. Кровь рассматривалась как неньютоновская жидкость со степенным законом связи напряжения со скоростью деформации, который позволяет описывать не только поведение жидкостей, но и суспензий. Пульсовой режим течения крови определялся заданием пульсирующего изменения параболического профиля скорости на входе в аорту. Поскольку принимаемое обычно для вязких жидкостей условие прилипания на границе не соответствует характеру взаимодействия потока крови со стенкой сосуда, то в качестве условия на границе было выбрано условие полупроскальзования. Для выполнения вычислений была построена геометрическая модель рассматриваемой части аорты, на которую была нанесена тетраэдальная сетка с общим числом элементов 9810. Вычисления производились методом конечных элементов с шагом по времени 0.01 с с использованием пакета ABAQUS. B результате было получено распределение скоростей и давления на каждом шаге по времени. В областях ветвления сосудов было обнаружено временное наличие вихрей и обратных течений. Они зарождались через 0.47 с от начала пульсового цикла и исчезали спустя 0.14 с. Библиогр. 9 назв. Ил. 10.

Ключевые слова: математическое моделирование, течение крови.
\end{abstract}

Introduction. As is known the blood has a complex internal structure consisting of liquid plasma and the set of blood cells (structural elements) which make up to

Tregubov Vladimir Petrovich - doctor of physical and mathematical sciences, professor; v.tregubov@spbu.ru

Mukhtarova Diana Hasanovna - master; muffy2006@mail.ru

Трегубов Владимир Петрович - доктор физико-математических наук, профессор; v.tregubov@spbu.ru

Мухтарова Диана Хасановна - магистр; muffy2006@mail.ru

(c) Санкт-Петербургский государственный университет, 2017 
46 percent of the total blood volume (Figure 1). Besides, the erythrocytes, which make up the largest volume percent of blood cells, are able to form aggregates in the form of so called "coin columns" (Figure 2). In this regard, blood can be considered as liquid only in large blood vessels where the characteristic sizes of the structural elements of blood and their aggregates are small compared to the diameter of the vessel cross section. The best example of this condition is the aorta. But even in this case the blood cannot be regarded as Newtonian liquid which in general is typical for most viscous liquids, having a homogeneous structure. In order to take into account, at least partially, the influence of the internal structure on the character of bloodstream the blood is often considered as non-Newtonian fluid, theory of which was represented in detail in [1]. In this case the concept of the so called apparent viscosity, which depends on the shear rate, is usually used. The influence of the non-Newtonian properties of blood on the flow in large curved arteries was studied in [2].

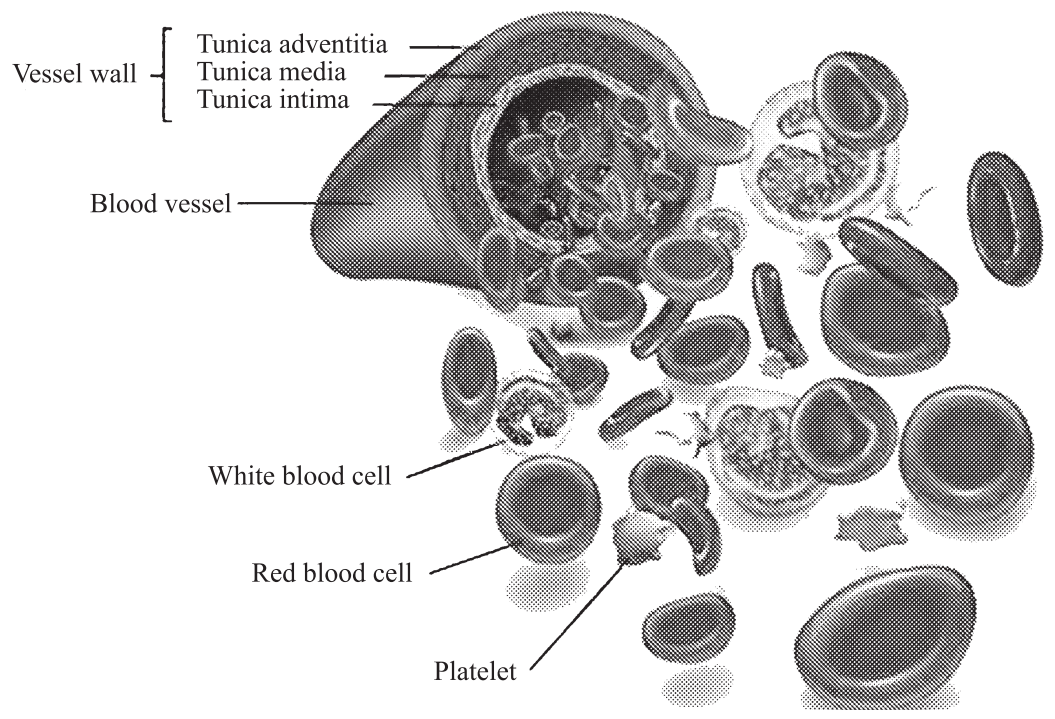

Figure 1. Complicated blood structure

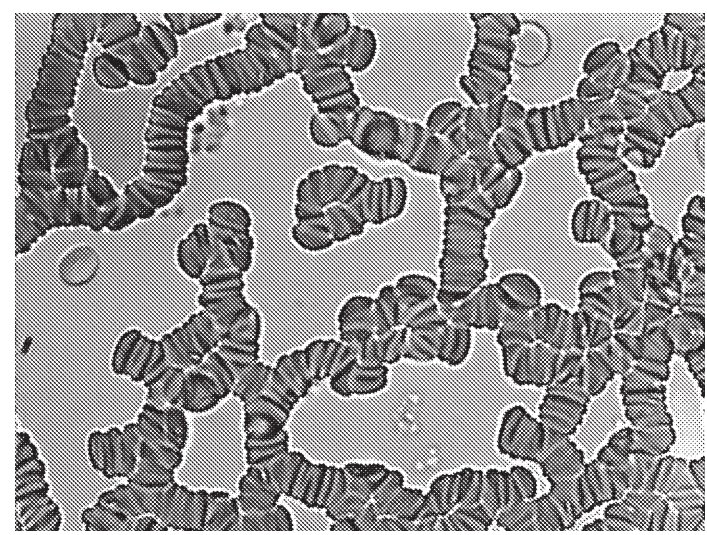

Figure 2. Generation of erythrocyte columns 
Along with this, a complicated spatial geometry of blood vessels and the presence of branching represent a substantial difficulty in modelling the flow of blood [3]. On the other hand these are the areas of significant interest to physicians.

Mechanical models of vessels and blood. Referring the above, the part of aorta including the ascending aorta, aortic arch with its branches (except the right common carotid artery) and the top of the descending aorta was chosen for the blood flow modelling (Figure 3).

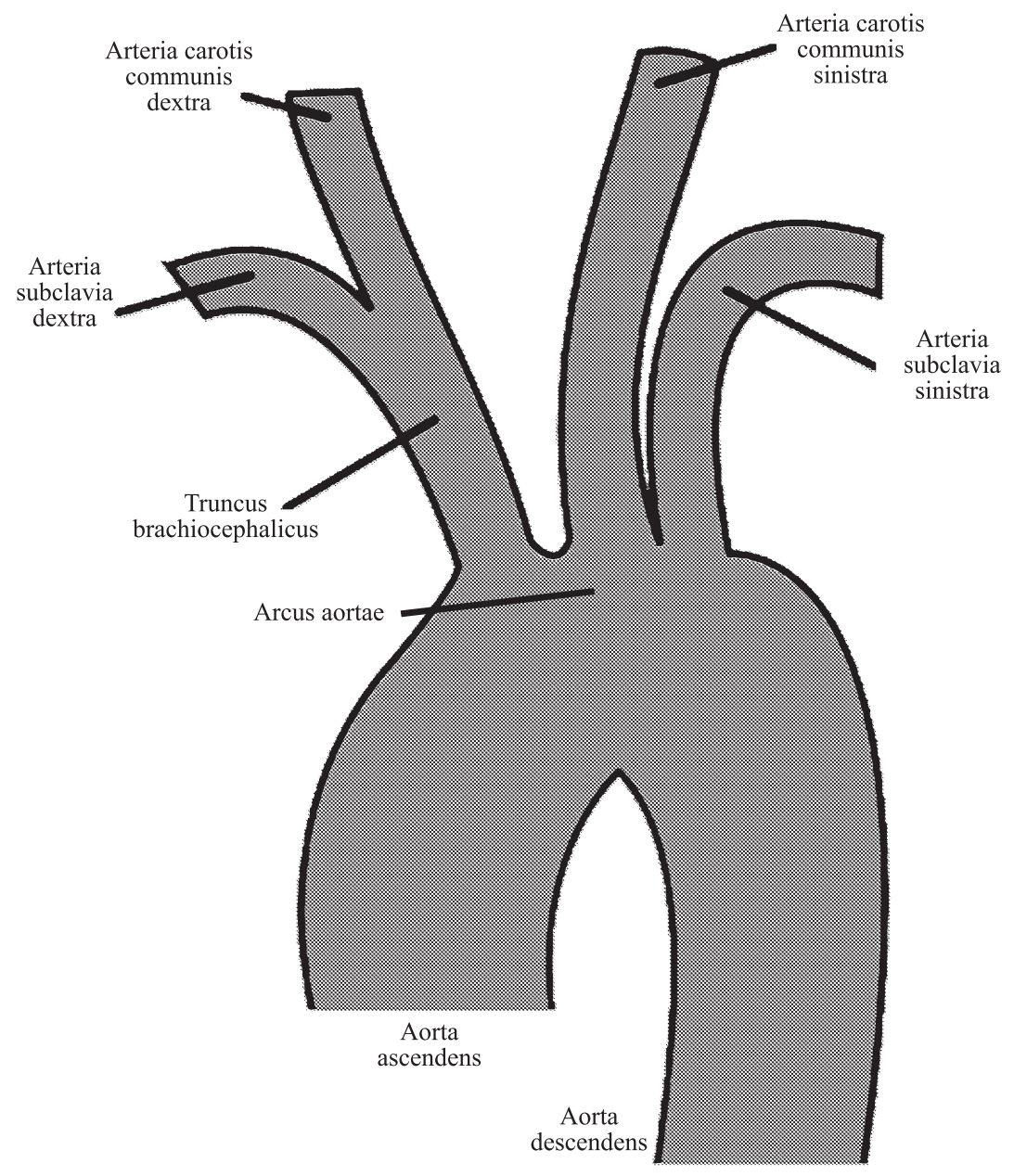

Figure 3. Upper part of aorta with branches

Mathematical modelling of blood flow in this region is based on the mechanical models of the blood and vessels. In doing so we considered the vessel walls as nondeformable, as well as many other authors (see, for example, [4, 5]). This is justified, at least for the aorta, since the vessel wall deformation is very small. The space structure of the model was constructed by means of circular cylinders with curved axes and smooth connections between them. This operation was performed by means of the computation system ABAQUS, which is described below. General view of the vessel mechanical model, constructed in such a way, is shown in Figure 4. 


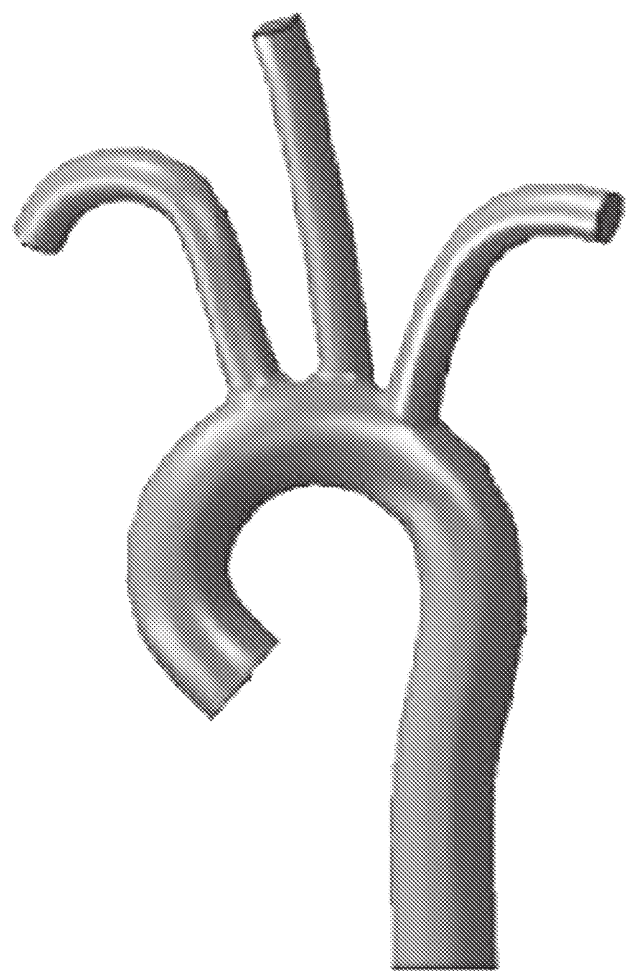

Figure 4. General view of the vessel mechanical model
Since the blood density in real physiological conditions without lack of blood loss does not vary by more than a few hundredths of a percent it can be considered as an incompressible fluid. In accordance with the modern conception of the blood mechanical properties formulated in the introduction the non-Newtonian fluid was chosen for the blood modelling, also Newtonian fluids are still sometimes used in solving the practical problems [6].

In the same time it is necessary to point out that there is the hole set of non-Newtonian liquids and each of them has its own laws, expressing the relation between the stress and shear rate. In particular, dilatant liquid is one of the non-Newtonian liquid specific kinds. This liquid usually represents a suspension with high content of solid particles, which can change their configuration, connect and disconnect with each other depending on a shear stress. That is why the dilatant liquid with its properties close to the properties of the blood was chosen for this study. We considered the most common for dilatant

fluid and convenient for calculation the power kind of relationship between the stress and shift velocity [7]. The expression for the apparent viscosity for the one-dimensional flow of the liquid is given by $\mu_{a}=k \dot{\gamma}^{n-1}$, where $k$ and $n$ are the power model parameters, that are typically considered to be constant.

In order to preset the pulsating blood flow at the input cross-section it is proposed to use a part of paraboloid of revolution in order to model the velocity distribution in this cross-section (Figure 5). The height of paraboloid part is changing in time from 0 to maximal velocity value. The total flow of blood passing through input cross-section is equal to the blood flow ejected into the aorta from the left ventricle (Figure 6). With regard to the boundary condition at the opposite cross-section, it is assumed so far away where the blood velocity can be considered constant and equal to the average flow velocity $v_{\text {aver }}$.

The particular attention has been given to the interaction between the blood and vessel wall. In the hydrodynamics of viscous liquids the no-slip boundary condition is usualy adopted. This condition can not be applied for the blood as a hole but only for the blood plasma. What actually happens is that the blood cells don't attach to the wall and slide along this wall or are repelled from it owing to their electro-chemical properties. This situation is sometimes called as full-slip condition. In order to average boundary conditions for the plasma and blood sells the so called semi-slip condition can be used. In this case longitudinal velocity $v_{\text {long }}$ is reduced to preset value $v_{0}$. It is common practice to express the degree of this semi-slipping by means of the parameter $b$, which is 
expressed as the distance between the vessel boundary line and the point $c$. In its turn $c$ is the intersection point of the tangent to the envelop curve and the vertical axis $y$.

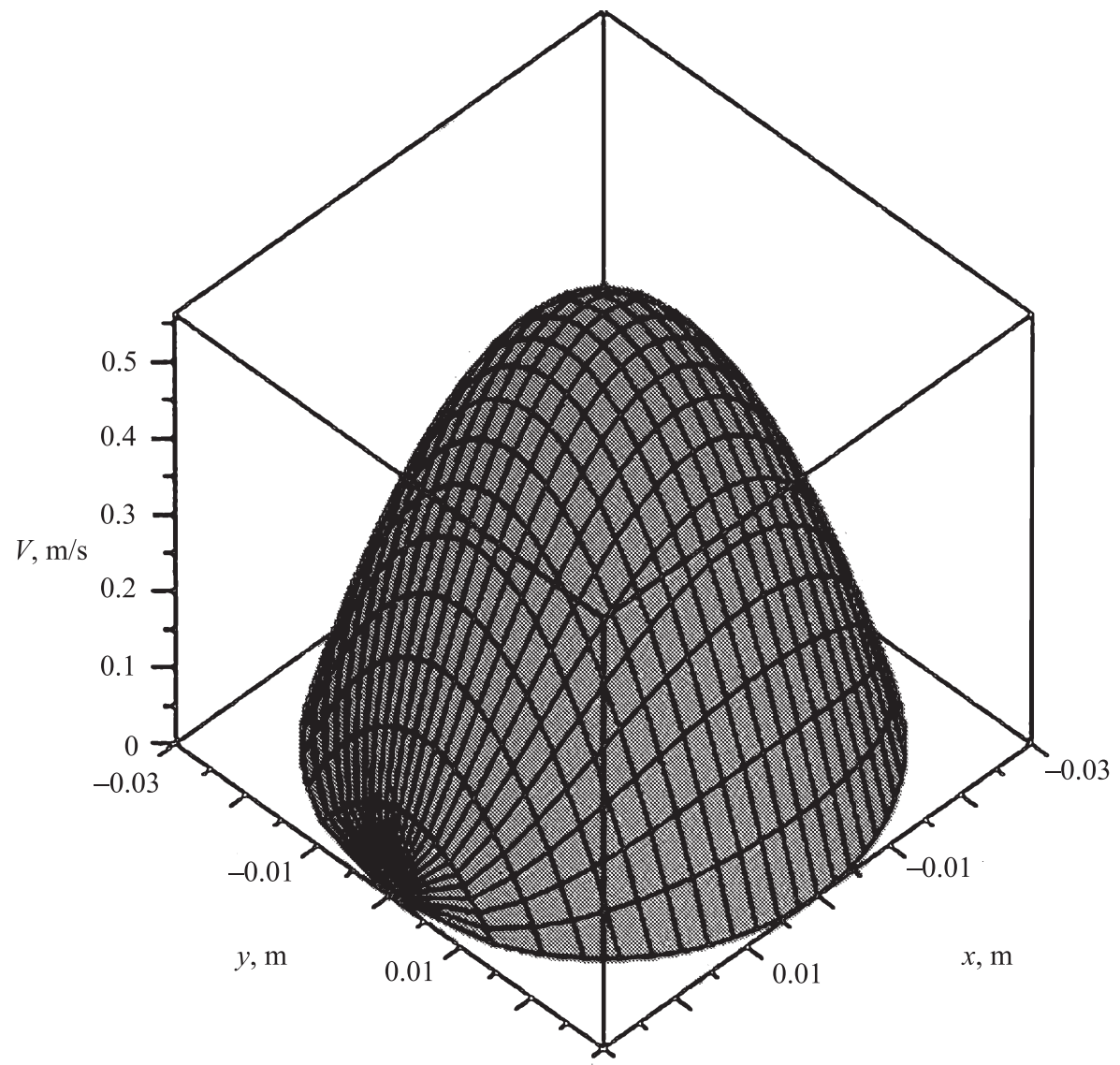

Figure 5. Spatial velocity profile at the entrance into aorta

Flow, $\mathrm{m}^{3} / \mathrm{s}$

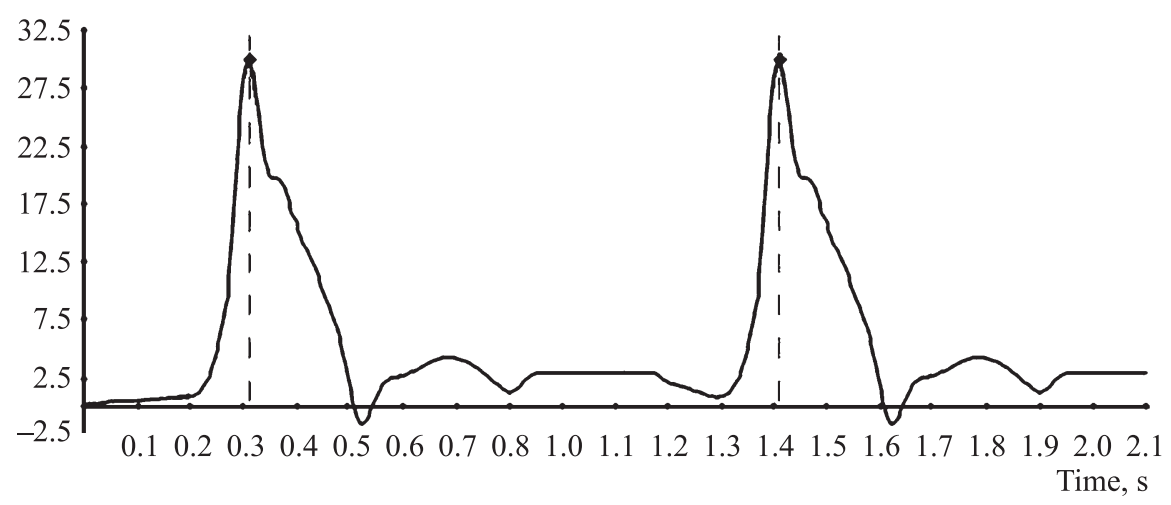

Figure 6. Blood flow ejected into aorta 
Mathematical description. In the three-dimension case the tensor representation of power law for the dilatant liquid has the following form:

$$
\mathbf{T}=2 k\left|I_{2}\right|\left(\frac{n-1}{2}\right) \mathbf{D},
$$

where $\mathbf{T}$ is the viscous stress tensor, $\mathbf{D}$ is the strain velocity tensor and $I_{2}$ is its second principal invariant of $\mathbf{D}$. Having the expression of this power law the system of governing equations for the blood flow can be written as

$$
\left\{\begin{array}{l}
\rho \frac{d \mathbf{v}}{d t}=\nabla(-p \mathbf{I}+\mathbf{T}), \\
\operatorname{div} \mathbf{v}=0
\end{array}\right.
$$

here $\mathbf{v}$ is the velocity vector, $\rho$ is the fluid density, $p$ is the pressure and $\mathbf{I}$ is the identity tensor.

In addition to these equations it is necessary to formulate the initial and boundary conditions. In order to start a calculating procedure it was adopted that at initial time instant the blood is at rest. That is

$$
\left.\mathbf{v}\right|_{t=0}=0
$$

This condition may be in particular realized just after the start up of the heart during the medical operation. The following is a modeling of the evolving process until steady state pulsating mode is reached.

At the input section of the considerable vessel part the pulsating change of the spatial velocity profile may be set in the cylindrical coordinates $r, \phi, v$ as a paraboloid of revolution in the following way:

$$
\left.\mathbf{v}(r, t)\right|_{\text {input }}=v_{\max }(t)\left(\frac{r^{2}}{r_{0}^{2}}+1\right),
$$

where $v$ is the longitudinal blood velocity, $r_{0}$ is the vessel radius at the input.

At the far output section the boundary condition may be written as

$$
\mathbf{v}=\text { const }=\mathbf{v}_{\text {aver }}
$$

The semi-slip condition is set as follows:

$$
\mathbf{v}_{\tau} \mid \text { wall }=\mathbf{v}_{0}=-\left.b\left(\frac{\partial \mathbf{v}_{\tau}}{\partial n}\right)\right|_{\text {wall }},
$$

where $\mathbf{v}_{\tau}$ is the tangent projection of velocity accordingly.

Calculations. For the calculation of the task the software package ABAQUS was used. This choice was due to the fact that ABAQUS has powerful tools for creating model geometry, calculations and their visualization. In the first step the geometry of model was created by the junction of curved cylinders using the joint smoothing procedure. After this the computational grid with tetrahedral elements was applied (Figure 7). The total number of the elements is equal 9810. The calculations were performed using Finite Element Method with time step $0.01 \mathrm{~s}$. 

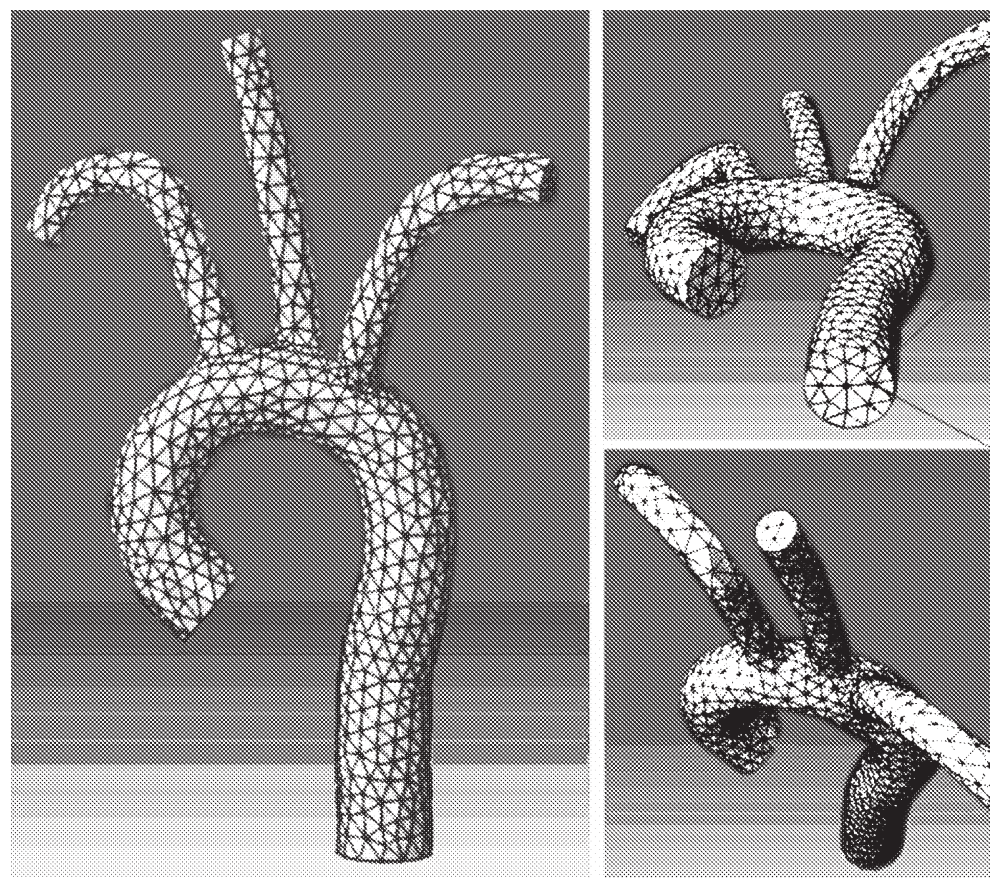

Figure \%. Geometry of model and calculation grid

Results. As a result of calculation with use of ABAQUS software the distribution of blood velocity and pressure in the considerable aorta part were obtained at each time moment during the pulse period. For example the blood pressure distribution at the time moment $t=0.3 \mathrm{~s}$ is presented in Figure 8 . This time point corresponds to the maximum

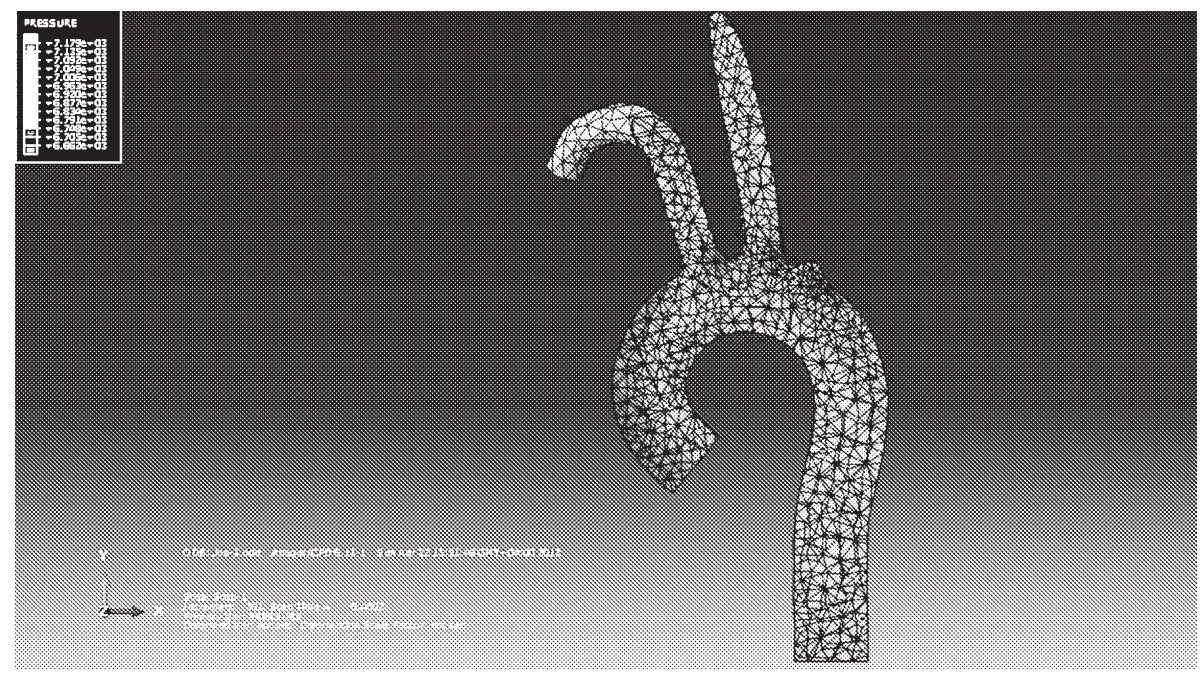

Figure 8 . The blood pressure distribution in the aorta at time $t=0.3 \mathrm{~s}$ 
flow ejected into aorta. The profiles of blood velocity in the aorta at time $t=0.3 \mathrm{~s}$ for a few sections are presented in Figure 9. It can be seen from this figure that the maximums of blood velocity profiles are shifted to the wall with a smaller radius of curvature. We should also pay a particular attention to the appearance of the vortices and reverse blood flows in the branching area, which are shown in Figure 10. These vortexes and reverse flows appear approximately at $t=0.47 \mathrm{~s}$ and disappear at $t=0.61 \mathrm{~s}$.

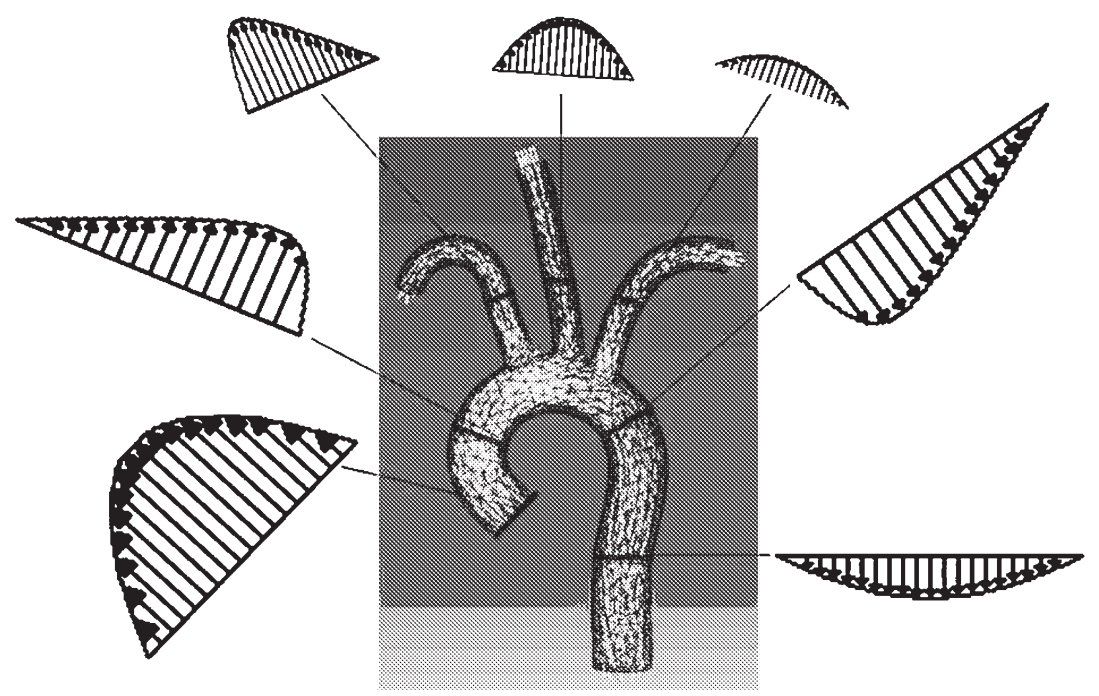

Figure 9. The blood velocity profiles in the vessel cross-sections at time $t=0.3 \mathrm{~s}$

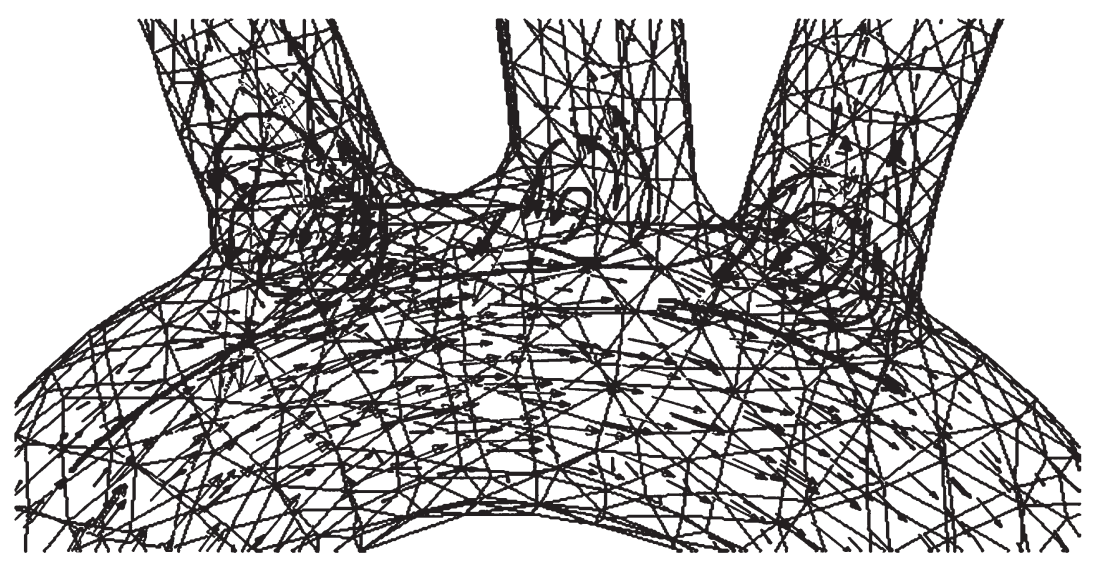

Figure 10. The generation of vortexes and reverse flows

Conclusion. In conclusion we can say that the proposed mathematical model has allowed to establish the characteristic features of blood flow in the presence of the vessel spatial curvature and branching, as well as to obtain numerical characteristics of these features.

In this case, despite the fact that the forms of vessel mechanical models are somewhat idealized in nature, the proposed method allows to deviate from this idealization, and to 
approximate the shape of the vessel to its real form for a particular patient, including cases of pathology.

Besides, the proposed method makes it possible to simulate vascular changes shape as a result of surgery for specific patient, in particular, after the Norwood operation, which was considered in [8]. This enables surgeons considering various options and predicting their results. Finally, the proposed model of the ascending aorta can be combined with the modeling of the left ventricle cinematic which was developed earlier [9].

\section{References}

1. Siginer D. A., De Kee D., Chhabra R. P. Advances in the Flow and Reology of Non-Newtonian Fluids. Intown, Elsevier Publ., 1999, 1515 p.

2. Gijsen F. J. H., Allanic E., Van De Vosse F. N., Janssen J. D. The influence of the nonNewtonian properties of blood on the flow in large arteries: unsteady flow in a 900 curved tube. Journal of Biomechanics, 1999, vol. 32, pp. 705-13.

3. Chen J., Lu X.-Y. Numerical investigation of the non-Newtonian blood flow in a bifurcation model with non-planar branch. Journal of Biomechanics, 2004, vol. 37, no. 12, pp. 1899-1911.

4. Hoogstraten H. W., Kootstra J. G., Hillen B., Krijger J. K. B., Wensing P. J. W. Numerical simulation of blood flow in an artery with two successive bends. Journal of Biomechanics, 1996, vol. 29, no. 8, pp. 1075-1083.

5. Papaharilaou Y., Doorly D. J., Sherwin S. J. The influence of out-in-plane geometry on pulsatile flow within a distal end-to-side anastomosis. Journal of Biomechanics, 2002, vol. 35, no. 9, pp. 1225-1239.

6. Quarteroni A., Tuveri M., Veneziani A. Computational vascular fluid dynamics: problems, models and methods. Computing and Visualization in Science, 2000, vol. 2, pp. 163-197.

7. Ratkina S. V., Tregubov V. P. Mathematical simulation of a blood stream in large arteries. Intern. Conf. of the Polish Society of Biomechanics. Book of abstr., 2010, pp. 187-188.

8. Migliavacca F., Yates R., Pennati G., Dubini G., Fumero R., De Leval M. R. Calculating blood flow from Doppler measurements in the systemic-to-pulmonary artery shunt after the Norwood operation: a method based on CFD. Ultrasound in Medicine and Biology, 2000, vol. 26, no. 2, pp. 209-219.

9. Tregubov V. P., Radichkina A. O. Matematicheskoe modelirovanie kinematiki levogo zheludochka serdtsa cheloveka $\mathrm{v}$ protsesse ego sokraschenia [Mathematical modelling of the left ventricle cinematic during a contraction]. Vestnik of Saint Petersburg University. Series 10. Applied mathematics. Computer science. Control processes, 2013, issue 4, pp. 67-73. (In Russian)

For citation: Tregubov V. P., Mukhtarova D. H. A model study of blood flow in branching vessels. Vestnik of Saint Petersburg University. Applied mathematics. Computer science. Control processes, 2017, volume 13, issue 1, pp. 42-50. DOI: 10.21638/11701/spbu10.2017.104

Статья рекомендована к печати проф. Н. В. Егоровым.

Статья поступила в редакцию 12 сентября 2017 г.

Статья принята к печати 19 января 2017 г. 